\title{
Między Żurawnem a Wiedniem O potrzebie dalszych badań nad systemem stałej dyslokacji wojska koronnego w latach 1677-1683
}

Streszczenie. W okresie między dwiema wojnami Rzeczypospolitej z Imperium Osmańskim (1677-1683) wojsko koronne zajmowało stałe kwatery na pograniczu polsko-tureckim. Celem żołnierzy była ochrona nowych granic - po oddaniu Turcji Podola - i oszczędzenie ludności cywilnej przed przemarszami oraz stacjonowaniem wojska w głębi kraju. W ten sposób utworzono pierwszy system koszar wojskowych, a żołnierze sami trudnili się produkcją żywności na własne potrzeby. Ten utrwalony w pamiętnikach z epoki obraz wymaga jednak potwierdzenia lub weryfikacji, przede wszystkim w oparciu o zespoły archiwalne ze Lwowa i Mińska.

Słowa kluczowe: wojsko koronne w latach 1677-1683, dyslokacja wojska koronnego w latach 1677-1683, pogranicze polsko-tureckie.

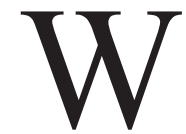

wyniku wojny z Porta 1672-1676 Rzeczpospolita utraciła Podole i większą część Ukrainy Prawobrzeżnej. Konflikt zakończył się rozejmem podtrzymującym niekorzystne postanowienia traktatu buczackiego z 1672 r. ${ }^{1}$ Mimo to, pod koniec 1676 r. pod kontrolą wojsk koronnych pozostawało kilka kluczowych miast podolskich oraz ukrainnych, jak Kalnik, Niemirów, Bar i Międzybóż, które w świetle traktatu powinny zostać wydane Turcji Osmańskiej. Liczono jednak, że wysłane wiosną 1677 r. do Stambułu poselstwo wynegocjuje zatrzymanie ich przez stronę polską. Do tego czasu zamierzano zabezpieczyć nowe, nieuregulowane pogranicze z Wysoką Portą, przebiegające pomiędzy ziemią halicką i Wołyniem a oddanym sułtanowi Podolem. Zabezpieczenie terenu pogranicznego powierzono armii koronnej, która w związku z zakończeniem działań wojennych musiała przejść redukcję do stanu 12150 koni i porcji (włącznie z załogami Krakowa i Lubowli - 12250 koni i porcji), jak postanowił sejm obradujący od 14 stycznia do 26 kwietnia 1677 r. Przejście wojska na etat poko-

*E-mail: zb.hundert@gmail.com.

${ }^{1}$ Szczegółowo: M. Wa g n e r, Wojna polsko-turecka w latach 1672-1676, t. I-II, Zabrze 2009. 
jowy, przy równoczesnym powierzeniu mu zadań natury strategicznej (zabezpieczenie polskiego stanu posiadania), próbowano połączyć z jeszcze jedną kwestią: koniecznością zareagowania na notorycznie pojawiający się problem wymuszeń żołnierskich (tzw. egzakcji) na ludności cywilnej, związanych z przemarszami na stanowiska i z pobytem na leżach zimowych w królewszczyznach ${ }^{2}$. Przykładów takich działań było wiele. Jeszcze na początku 1676 r. skarżono się na tak renomowane oddziały wojska koronnego, jak chorągiew husarską chorążego koronnego Mikołaja Hieronima Sieniawskiego, czy chorągwie dragońskie z regimentu gwardii królewskiej Jana III, które dokonały szkód oraz rozbojów w dobrach dziedzicznych wojewody krakowskiego Aleksandra Michała Lubomirskiego ${ }^{3}$.

Na mocy ustawodawstwa sejmowego i decyzji komisji wojskowej lwowskiej, zakończonej 25 lipca 1677 r. $^{4}$, dla zredukowanego wojska koronnego ustalono stałe miejsca na granicy w sześciu partiach ${ }^{5}$. Zgodnie z instrukcją dla komisarzy królewskich, wydanej z kancelarii 17 maja 1677 r., w lipcu dokonano wyceny majętności, w których miało być lokowane wojsko. Wycena, zarejestrowana 6 sierpnia 1677 r. w grodzie lwowskim, przewidywała, że właściciele majątków otrzymają zadośćuczynienie za udostępnienie swoich włości żołnierzom na kwatery o łącznej wysokości 106000 zł - co przekraczało o 3000 wstępną kalkulację ${ }^{6}$.

${ }^{2} \mathrm{O}$ okolicznościach i przyczynach wprowadzenia systemu dyslokacji w 1677 r. szeroko: Z. Hund ert, Dyslokacja partii wojska koronnego w 1677 roku. Przyczynek do badań pogranicza polsko-tureckiego oraz organizacji armii w dobie pokoju 1677-1683, „Klio: Czasopismo poświęcone dziejom Polski i powszechnym" 2016, nr 1 (36), s. 42-49.

3 Vide: Wypisy dwóch protestacji z 1676 r., z ksiąg grodzkich sandomierskich, z regestrem szkód popełnionych przez postój husarii Sieniawskiego i dragonów królewskich we wsi Tuszyma A.M. Lubomirskiego, Archiwum Główne Akt Dawnych w Warszawie [dalej: AGAD], Archiwum Lubomirskich z Małej Wsi, sygn. 1604, s. 4-12. Więcej w kwestii badań nad przestępstwami żołnierskim w świetle protestacji z ksiąg grodzkich i ziemskich vide: M. N a g i e l s k i, Żotnierz koronny w XVII wieku. Wybawca i bohater czy ciemiężyciel - w świetle zachowanych rejestrów szkód w księgach grodzkich i ziemskich Rzeczypospolitej, [w:] Społeczeństwo Staropolskie, t. IV (Społeczeństwo a wojsko), red. I. Dacka-Gorzyńska, M. Nagielski, A. Karpiński, Warszawa 2015, s. 135-154.

${ }^{4}$ Ze Lwowa, 25 VII 1675, Biblioteka Książąt Czartoryskich w Krakowie, rkps 175, s. 336.

${ }^{5}$ Dokładny wykaz rozmieszczenia poszczególnych oddziałów wojska koronnego w systemie dyslokacji z 1677 r. został zamieszczony w: Z. Hu n d ert, op. cit., s. 50-59. Wykaz ten został przygotowany na podstawie jedynego znanego, jak dotąd, dokumentu z epoki, który ilustruje przydział poszczególnych oddziałów armii koronnej do partii w 1677 r. Vide: AGAD, Archiwum Zamoyskich [dalej: AZ], sygn. 3112, s. 474-477; cf. M. Wa g n er, Armia koronna w latach 1677-1678, [w:] Król Jan III Sobieski i Rzeczpospolita w latach 1674-1683, red. D. Milewski, Warszawa 2016, s. $184-187$.

${ }^{6}$ Oblata commissionis pro stativis Exercitus Regni peractae (oblata 6 VIII 1677), Centralnyj Derżawnyj Istorycznyj Archiw Ukraini, m. Lviv [dalej: CDIAUL], F. 9, op. 1, ks. 435, s. 1408-1413; Instrukcyja ichmościom pp. komisarzom do lokacyjej wojska ordynowanym, wydana z kancelariej d. 17 maj an. 1677, AGAD, AZ, sygn. 3112, s. 464-465 (tu informacja, że do ksiąg lwowskich wycenę oblatowano 15 VIII 1677); M. Wagne r, Armia koronna..., s. 184. Komisarzami było siedem osób - cztery z senatu i trzy ze „stanu rycerskiego": kasztelani - lwowski Marcin Zamoyski, lubaczewski Wiktoryn Stadnicki, biecki Andrzej Michał Kuropatnicki, halicki Stefan Zamoyski; spoza 
Równocześnie trwała lokacja. Cztery partie rozlokowano w ziemi halickiej, a dwie największe (pod Buczniowem i Trembowlą) bezpośrednio podlegały hetmanom koronnym:

1. Partia pod Buczniowem, wojewody bełskiego i hetmana wielkiego koronnego Dymitra Wiśniowieckiego (2930 koni i porcji) ${ }^{7}$.

2. Partia pod Trembowlą wojewody ruskiego i hetmana polnego koronnego Stanisława Jana Jabłonowskiego (4500 koni i porcji) ${ }^{8}$.

3. Partia pod Borkiem chorążego koronnego Hieronima Augustyna Lubomirskiego (1060 koni) ${ }^{9}$.

4. Partia pod Rakowcem - Śniatyniem strażnika koronnego Stefana Bidzińskiego (1020 koni $)^{10}$.

Dwie najmniejsze partie stanęły na Wołyniu i w polskiej części Prawobrzeża (starostwo dymirskie):

1. Partia pod Krzemieńcem podkomorzego włodzimierskiego Jerzego Wielhorskiego (520 koni) $)^{11}$.

2. Partia pod Dymirem skarbnika halickiego Stanisława Sariusza Łazińskiego (vel Łaźnińskiego, 290 koni) ${ }^{12}$.

Odrębną część w systemie dyslokacji oddziałów komputowych stanowiły załogi twierdz ukrainnych i podolskich: Białej Cerkwi, Pawołoczy, Kalnika, Niemirowa, Baru i Międzyboża ${ }^{13}$.

senatu: podkomorzy włodzimierski Jerzy Wielhorski, starosta chełmski Michał Florian Rzewuski i podstoli lubelski Zbigniew Bliskowski. Czterech z nich było wysokimi oficerami (pułkownikami) wojska koronnego (M. Zamoyski, Wielhorski, Rzewuski, Bliskowski) - a jeden nawet dowódcą partii wołyńskiej (Wielhorski). Vide: Konstytucje sejmu 1677 r., [w:] Volumina legum [dalej: Vol. leg.], t. V, oprac. J. Ohryzko, Petersburg 1860, s. 223.

78 chorągwi husarskich (770 koni), 8 chorągwi pancernych (630 koni), kompania arkabuzerii (100 koni), 2 roty jazdy wołoskiej (110 koni), regiment dragonii (300 koni), 4 regimenty piechoty niemieckiej ( 820 porcji) rota piechoty węgierskiej (200 porcji).

813 chorągwi husarskich (1300 koni), 12 chorągwi pancernych (770 koni), 2 roty jazdy wołoskiej (130 koni), regiment dragonii (300 koni), 7 regimentów piechoty niemieckiej (1860 porcji), rota piechoty węgierskiej (100 porcji).

912 chorągwi pancernych (660 koni), 400 koni z regimentu dragońskiego gwardii królewskiej.

1010 chorągwi pancernych (640 koni), 2 roty wołoskie (80 koni), regiment dragonii (300 koni).

116 chorągwi pancernych (320 koni), 200 koni z regimentu dragońskiego gwardii królewskiej.

122 chorągwie pancerne (100 koni), 4 roty wołoskie (190 koni). Oprócz niej, w starostwie dymirskim stacjonowali również Kozacy zaporoscy na służbie królewskiej.

134 chorągwie jazdy wołoskiej (170 koni), 8 regimentów piechoty niemieckiej (1540 porcji). Dodatkowo, jeden z regimentów komputowych (120 porcji) obsadzał zamek lwowski. 
Dzięki temu rozmieszczeniu konieczność ściągania wojska do specjalnie zakładanych co rok obozów i następnie kierowania ich zimą na leża miała już nie występować. Konstytucja sejmowa nakazywała w końcu żołnierzowi, że ,żadnych in posterum konsystencyi, redutów, stanowisk, wytchnienia, victualia, popasów koni, ani quoquo nomine nazywanych egzakcyi w dobrach in genere wszystkich państwa naszego pretendować nie ma, ani ciągnieniem, marszami, werbunkami, więcej ubogim ludziom naprzykrzać się"14. System lokacji wojska w tym kształcie funkcjonował do 1683 r. - czyli do czasu zwiększenia armii koronnej na potrzeby wojny z Portą Osmańską - i to na zupełnie innym obszarze działań wojennych. Gdy w sierpniu 1682 r. król Jan III zwracał się do senatorów za pomocą listów deliberatoryjnych z pytaniem, co czynić, gdy zagrożenie osmańskie pojawiło się na Górnych Węgrzech (Słowacji) - i może być silniejsze niż na pograniczu z Podolem - i czy wówczas ,expedit dzielić korpus wojska albo przenosić strażnice prawem ocerklowane na granice nowemu podległe niebezpieczeństwu?"15. Uwagę zwraca przede wszystkim podkreślenie faktu, że dotychczasowe pozycje partii wojska koronnego były sankcjonowane prawnie, co blokowało próby ich poważniejszej reorganizacji. Dlatego jedyne zmiany, jakie zaszły w systemie dyslokacji do czasów sejmu 1683 r., to zejście w 1678 r. polskich garnizonów z miast wydanych Porcie i zasilenie dotychczasowych partii albo załóg twierdz, przede wszystkim Stanisławowa i Białej Cerkwi ${ }^{16}$. Ten fakt umknął niektórym żołnierzom, kreślącym po latach swe wspomnienia, albowiem odnotowywali oni zgodnie, że wojsko w okresie 1677-1683 stało ciągle na tych samych pozycjach. Wyjątkiem był tu rok 1680, gdy w związku z rozgraniczeniem polsko-tureckim ${ }^{17}$ armia koronna została ściągnięta do wspólnego obozu pod Mikulińce. Jak zanotował jednak anonimowy żołnierz, ,po tym nazad, gdzie kto stał, rozeszli się, po rozgraniczeniu z Turkami" ${ }^{18}$. Podobnie zaznaczył Franciszek Pułaski, myląc się tylko w datacji (wskazał rok 1681, a nie 1680) - „rozgraniczenie z Turkami, dla czego wojsko było ściągnięte pod Mikulińce, po tym na swoje stanowiska rozeszło się"19.

14 Konstytucje sejmu 1677 r., [w:] Vol. leg., t. V, s. 223.

15 Literae Regis deliberatoriae ad senatores, Jaworów 22 VIII 1682, [w:] Akta do dziejów króla Jana III sprawy roku 1683, a osobliwie wyprawy wiedeńskiej wyjaśniające, oprac. F. Kluczycki, Kraków 1883, s. 3; cf. J. Wi m m e r, Wiedeń 1683. Dzieje kampanii oraz bitwy, Warszawa 1983, s. 129.

16 Z. Hundert, op. cit., s. 64-65. Dokąd dokładnie udała się grupa chorągwi i regimentów, które w 1678 r. opuściły Kalnik, Bar, Międzybóż i Niemirów (4 roty wołoskie i 6 regimentów pieszych - razem 1250 koni i porcji) wymaga kolejnych badań.

17 Ostatnio o rozgraniczeniu polsko-tureckim: K. K o c ze garow, Rzeczpospolita a Rosja w latach 1680-1686. Zawarcie traktatu o pokoju wieczystym, tłum. z jęz. rosyjskiego z uzupełnieniami, red. T. Szwaciński, Warszawa 2017, s. 87-94.

18 Wojna $w$ Polszcze poczynająca się od Kozaków w roku 1648 [do 1701], Lvivska Nacional'na Naukova Bibliotieka Ukrajiny imieni Wasylja Stefanyka, F. 5 (Ossolińscy), op. 1, rkps 699, k. 14v; Z. Hundert, op. cit., s. 63-64.

19 F. P uła s ki, Krótka annotacja sejmów warszawskich, grodzieńskich, także elekcyi i koronacyi najjaśniejszych królów ichmościów polskich Jana Kazimierza, Michała, Jana III i Augusta II; 
Pułkownik wojska koronnego - cześnik, a od 1682 r. chorąży poznański Mikołaj Złotnicki - wskazał z kolei, że w latach 1681-1682 (podobnie zresztą jak w latach 1677-1679): „na zimę znowu wojsko na swoich miejscach rozłożone. Tamże wojsko rozłożone w pokoju"20. Wykorzystane diariusze, a właściwie kalendaria wydarzeń prowadzone przez żołnierzy armii koronnej, dowodzą, że w świadomości ich autorów okres między Żurawnem a Wiedniem charakteryzował się spokojem i stabilnością, które były nie tyle efektem polsko-tureckiego pokoju, ile funkcjonującego wówczas stałego systemu kwaterunku wojska.

System dyslokacji spełniał zadania obronne, polityczne ${ }^{21}$, a także ekonomiczne. W tej ostatniej materii, zgodnie z opiniami świadków epoki, dyslokacja się sprawdziła, odznaczając się wyraźnym nowatorstwem, zwłaszcza w aspekcie aprowizacji żołnierzy. Francuz Filip Dupont - dworzanin i inżynier Jana III, widział ją następująco: „Ponieważ żołnierze zawsze postępowali zbyt samowolnie i często wychodzili ze swych kwater i łupili chłopów, włócząc się bez potrzeby i bez rozkazu, król - chcąc ukrócić te nieporządki - zadysponował, że armia nie będzie już stacjonować w prowincjach, ale zawsze na granicy państwa, na obrzeżach krain spustoszonych przez Tatarów. Wytyczono więc miejsca na obóz, który kazano umocnić piechocie, i niebawem żołnierze otrzymali kwatery dość wygodne na każdą porę roku, takie jak Polacy potrafią budować, lepiej niż jakakolwiek inna nacja. Najbardziej zaludnione i najbliższe krainy dostarczały pod dostatkiem wszystkiego, czego potrzebowały wojska. Jazda zebrała takie ilości siana na stepie, który obfituje w trawę, że zawsze było go nadto. W ten sposób armii nie brakowało niczego, a chłopi byli zadowoleni. Można powiedzieć, że środki zaradcze, jakie przedsięwziął król, by ograniczyć samowolę wojska, stanowią niemałą przysługę oddaną państwu" 22 .

W opinii Duponta, wprowadzony w 1677 r. system zapewnił wojsku dość wysoki poziom egzystencji ze względu na wysokiej jakości kwatery oraz brak problemów z aprowizacją, co niewątpliwie przekładało się na morale i ogólną

tudzież za panowania ich kampanii corocznie odprawionych; publiczniejszych dziejów i rewolucyi ab anno 1648, ad annum 1733, Lublin 1740, f. B4.

${ }^{20}$ Mikołaj Ztotnicki i jego diariusz wojenny, oprac. M. Wagner, „Biuletyn Biblioteki Jagiellońskiej” 1994, t. XLV, nr 1/2, s. 121.

${ }^{21}$ Chodzi tu przede wszystkim o kwestię zapewnienia wpływów w wojsku koronnym królowi Janowi III i ograniczenie pozycji hetmana wielkiego D. Wiśniowieckiego. Z tego m.in. względu król oparł się na hetmanie polnym Jabłonowskim i innych swoich współpracownikach (m.in. H.A. Lubomirski, S. Bidziński), kontrolujących większość partii armii koronnej - w tym tej największej - pod Trembowlą (tam stanęły niemal wszystkie chorągwie i regimenty królewskie). Vide: Z. H u n d e rt, Pozycja Jana III w wojsku koronnym w latach 1674-1683. Utrzymanie czy też utrata wpływów wypracowanych w czasie sprawowania godności hetmańskiej?, [w:] Król Jan III Sobieski i Rzeczpospolita..., s. 134-135; i d e m, Dyslokacja partii..., s. 60-63; cf. M. Wa g n e r, Armia koronna..., s. $182-183$.

${ }^{22}$ F. Dupont, Pamiętniki historyi życia i czynów Jana III Sobieskiego, thum. B. Spieralska, oprac. D. Milewski, Warszawa 2011, s. 136. 
sprawność żołnierzy (aspekt nie do przecenienia w momencie podjęcia decyzji o wyruszeniu pod Wiedeń w 1683 r.).

Dupontowi wtórował jeden z najbardziej znanych pamiętnikarzy tego okresu - Jan Chryzostom Pasek. Notował on, że: „obóz zaś stał pod Trembowlą dobrze bardzo i wygodnie, bo sobie żołnierze gospodarowali, siali, orali, i łąki kosili $\mathrm{i}[\mathrm{w}]$ zimie taką wygodę mieli jak w domu, i na bazarze taniej wszystko niżeli po miastach, bo w obozie piwa i miody warzono i wozy tak szły na targi w majdan, jak przed laty do Kazimierza. Ordynacyja wojska bardzo dobra; gdyby tak zawsze, lepiej by niżeli się po Polszcze włóczyć na stanowisko i z stanowiska konie wniwecz obracać" 23 .

Pasek potwierdza pozytywny obraz, nakreślony przez Duponta, eksponując przede wszystkim aspekt samowystarczalności wojska w zakresie aprowizacji, a także fakt, że stacjonowanie w jednym miejscu przez cały rok było świetnym rozwiązaniem, albowiem żołnierze nie byli narażeni na forsowanie i utratę koni podczas przemarszów na stanowiska.

Obraz wojska na kwaterach $\mathrm{w}$ omawianym okresie, zgodny z powyższymi opiniami, ale nie aż tak w swej wymowie pozytywny, nakreślił również obywatel województwa bełskiego i były żołnierz, Mikołaj Jemiołowski: „Zrazu zaraz na troje dobra pewne pod Trembowlą, pod Buczniową i pod Krzemieńcem komisarze naznaczeni pokupiwszy, czy też tylko na kredyt u Rzeczypospolitej wziąwszy, między żołnierzów rozdali i pewną kwotę wojska na tych tu trojgu miejscach według proporcyi rozłożyli i żeby sobie jako chcieli i mogli zbóż i sian przysposabiali, upomnieli, ażeby hiberny pewnej na święty Marcin [tj. 11 listopada - przyp. Z.H.] spodziewali się, upewnili.

I rzuciło się było wojsko do gospodarstwa. Chałupki pobudowali, siali, siana zbierali, a kiedy święty Marcin przyszedł, a hiberny ledwie co było widać nie tylko w obozach, ale i we Lwowie, jak znowu zamarkotne to im zdało się i tak kto rozumiał do domów rozjeżdżać się poczęli, tam tylko na kwaterach mieszkali, czeladzi zostawując. Rzadka chorągiew co by kilku towarzystwa przy sobie miała, bo nie tylko hiberna, ale i zasługi »jak na raku« do nich dochodziły.

O czym dowiedziawszy się Tatarowie spod Kamieńca, że się wojsko tak zmniejszyło, na tych miłych gospodarzów napadli i gdzie mogli po lasach goszczących siana zabierali, a drugich i zabijali" ${ }^{24}$.

Jemiołowski również podkreślił aspekt gospodarności żołnierzy na stałych kwaterach, przejawiającej się w produkcji rolnej na własne potrzeby. Ponadto zwrócił uwagę, że mimo dostatku żywności i paszy, braki w regularnym dowozie środków finansowych - tak żołdu, jak świadczenia wydawanego zimą,

${ }^{23}$ J.Ch. P a s e k, Pamiętniki, oprac. W. Czapliński, Warszawa 2009, s. 511; M. Wa g n e r, Armia koronna..., s. 186-187.

${ }^{24}$ M. Je mi oł o w s k i, Pamiętnik dzieje Polski zawierajacy (1648-1679), oprac. J. Dzięgielewski, Warszawa 2000, s. 473-474; M. Wa g n er, Armia koronna..., s. 186. 
tj. hiberny ${ }^{25}$, skutkowały rozjeżdżaniem się kadry dowódczej i towarzyskiej do domów. Wskutek tego chorągwie były nieliczne (na kwaterach zostawać miała sama czeladź), przez co narażono się na ataki ze strony Tatarów lipkowskich z załogi kamienieckiej - napadali oni bowiem na gospodarujących wojskowych, zabierając im zebrany prowiant.

Opinie świadków epoki przeniknęły do skromnej wciąż literatury przedmiotu, odnoszącej się do systemu dyslokacji wojska w latach 1677-1683. Wbrew opiniom Duponta czy Paska, Jan Wimmer stwierdził, powołując się na lekturę uchwał sejmikowych, że chorągwie nie pozostawały nieprzerwanie na swoich kwaterach i wkraczały do województw dalej położonych ${ }^{26}$. Te przypadki mogły mieć jednak charakter indywidualny, a nie ogólny. Za przykład służy kompania arkabuzerii królewskiej pod starostą starogardzkim Janem Górzyńskim (vel Gorzeńskim), która w listopadzie 1677 r. stała w opactwie jędrzejowskim i nie śpieszyła się, by dołączyć do swojej partii pod Buczniowem ${ }^{27}$. Na pewno jednak pobytu żołnierzy w dobrach w ziemi halickiej doświadczyli ich sąsiedzi, co ma odzwierciedlenie w skargach składanych stanom sejmującym za pośrednictwem instrukcji sejmikowych ${ }^{28}$.

${ }^{25} \mathrm{~W}$ roku, pod którym Jemiołowski zamieścił tę informację, a więc w 1677, komisja hibernowa zebrała się dosyć szybko - dystrybuta rozpoczęła się już bowiem 15 października, choć asygnacje hibernowe dla poszczególnych jednostek noszą datę 6 XI 1677. Vide: Deklaracyja wybierania hiberny z dóbr króla jmści i Rzptej na św. Michat [tj. 29 września] we Lwowie, przez ichmościów pp. komisarzów, tak od Rzptej sejmem naznaczonych, jako i od wojska deputowanych, postanowiona, we Lwowie na komisyjej hibernowej d. 15 8bris 1677, AGAD, AZ, sygn. 3112, s. 467-469 - oblata tego dokumentu w grodzie lwowskim z 18 X 1677, CDIAUL, F. 9, op. 1, ks. 435, s. 1953-1955; liczne asygnacje hibernowe hetmana D. Wiśniowieckiego, Lwów 6 XI 1677, ibidem, s. 2128-2344.

${ }^{26}$ J. Wimmer, Wojsko polskie $w$ drugiej połowie XVII wieku, Warszawa 1965, s. 198; cf. M. Wagner, Armia koronna..., s. 182.

27 Z. Hundert, Dyslokacja partii..., s. 64.

28 Vide: Instrukcje sejmikowe ziemi halickiej, Halicz, 28 XI 1678, 26 XI 1680, 8 I 1683, [w:] Akta grodzkie i ziemskie z czasów Rzeczypospolitej Polskiej z archiwum tak zwanego bernardyńskiego we Lwowie, t. XXIV (Lauda sejmikowe halickie 1575-1695), oprac. A. Prochaska, Lwów 1931, s. 418, 429, 439-440. Szczególnie interesujące są skargi z instrukcji sejmikowej przed sejmem z 1683 r.: „Ponieważ dotychczas nie była in executione konstytucja sejmu 1677 o konsystencjach wojska na granicach uchwalona i wiele obywatelów nie tylko żeby mieli mieć za szkody swoje ukontentowanie pro tunc, ale jeszcze in dies ponoszą spustoszenie lasów, bez których wojsko obejść się nie może, także i insze szkody patiuntur, jako to jmp. Marcin Bogusz, podstoli nowogrodzki haeres Janowa jmść pp. Baworowscy, haeredes Baworowa i innych, jmp. [Jan] Strzemeski, posesor Mikuliniec, który nie tylko w lasach i gruntach mikulińskich, jako i w swoich dziedzicznych pod Śniatyniem znaczne ponosi iacturas, ale i w zbożach stratowanych przez wojska pod Mikulińce zgromadzone podczas rozgraniczenia srogą odniósł szkodę, jmp. Ruszkowska, possesstrix Petrykowa, jmść pp. Jastrzębscy, którzy wszyscy wspomnieni żadnej od Rzptej dotychczas nie mieli nagrody a ustawicznie dobra ich pustoszą się, jmść pp. posłowie starać się powinni, aby na rekompensę pomienionym ichmościom Rzpta sumę proporcjonalną ordynowała, czego odstąpić nie będą powinni". 
Przytoczone wyżej opinie domagają się wręcz podjęcia kolejnych badań i wykazania, czy w pełni oddawały one stan faktyczny? Większa część wojska koronnego stacjonowała w ziemi halickiej (partie spod Buczniowa, Trembowli, Borka i Rakowca - Śniatynia), wskutek czego musiała ona pozostawić ślad w aktach grodzkich i ziemskich z obszaru województwa ruskiego - przede wszystkim ziemi halickiej (grody w Haliczu i Trembowli). Analiza materiału zawartego w księgach grodzkich i ziemskich, przechowywanych w Centralnym Państwowym Historycznym Archiwum Ukrainy we Lwowie, w celu poszerzenia wiedzy na temat dyslokacji wojska koronnego w omawianym okresie, powinna stanowić pierwszy etap kwerendy. Dzięki niej będzie można rozpoznać kwestie codziennego funkcjonowania armii oraz dokonywane przez żołnierzy transakcje handlowe. Nieodzowną częścią kwerendy będzie zapoznanie się również z korespondencją wojskowych z osobą króla, przede wszystkim z lat 1680-1682, która zachowała się w mińskim Historycznym Narodowym Archiwum Białorusi w tzw. fondzie Sobieskich (fond 695) i nie stanowiła dotąd przedmiotu analizy badawczej ${ }^{29}$. Nie mniejszą rolę odgrywać będzie eksploracja materiałów krajowych, nie badanych dotąd pod kątem stałej dyslokacji wojska w latach 1677-1683. Podjęcie szeroko zakrojonych badań nad tytułowym problemem mogłoby zaowocować powstaniem dużej monografii poświęconej życiu codziennemu wojska w okresie pokoju i jego relacjach $\mathrm{z}$ lokalnymi społecznościami, ale także jego roli $\mathrm{w}$ zabezpieczeniu pogranicza i realizowania polityki wpływowych środowisk politycznych Rzeczypospolitej. Jestem w stanie zaryzykować stwierdzenie, że podzielenie wojska koronnego na partie w latach 1677-1683 było pierwszą udaną próbą w historii polskiej wojskowości stworzenia systemu koszar. Ze względu na specyfikę prowadzenia działań wojennych w latach 1683-1699, system ten został zaniechany, aczkolwiek ogólna tendencja do tego, że wojsko ma być lokowane na granicach, została podtrzymana, czego wyrazem była konstytucja sejmu $1685 \mathrm{r}^{30}$

Szczegółowe rozpoznanie zadań oraz codziennego funkcjonowania armii koronnej w okresie pokoju 1677-1683, w ramach dyslokacji, którą dość pozytywnie ocenili wskazani wyżej świadkowie epoki, stanowi niewątpliwie ważne przedsięwzięcie. Pozwoli to bowiem poznać, w jaki sposób wojsko koronne starego zaciągu (to, które od 1677 r. było rozłożone w sześciu partiach i to, które stanowiło trzon armii odsieczowej, skierowanej w 1683 r. pod Wiedeń), utrzymało swoją sprawność bojową i wewnętrzną spójność. Wystarczy zwrócić uwagę na sam fakt, że partie wojska rozłożone na granicach ziemi halickiej z Podolem latem $1683 \mathrm{r}$. niemal w rekordowym tempie pokonały kilkaset kilometrów, by dotrzeć na Śląsk,

\footnotetext{
${ }^{29}$ Nacjanalnyj Histaryczni Archiu Bełarusi, F. 695, op. 1, sygn. 48, 55, 99, 100, 142 i inne. Informacje te zawdzięczam uprzejmości Jana Jerzego Sowy.

${ }^{30}$ Konstytucje sejmu warszawskiego 1685 r., [w:] Vol. leg., t. V, s. 346-347 (konstytucja: Konsystencje wojska koronnego).
} 
a następnie pod Wiedeń ${ }^{31}$. W okolicznościach, w których od 1677 r. tylko raz opuściło swoje stanowiska - w 1680 r. - gdy stanęło wspólnym obozem w związku z czynnościami polsko-tureckiego rozgraniczenia, fakt szybkiego przemarszu dobrze zorganizowanych jednostek jazdy i piechoty wzbudza uznanie. Niewątpliwie sukces wiedeński, który rozsławił imię Rzeczypospolitej i polskiego oręża, miał jedno ze swoich źródeł w systemie dyslokacji lat 1677-1683, który podtrzymał sprawność bojową i ducha walki rozlokowanych w jego ramach jednostek.

\section{Bibliografia}

\section{ŹRÓDEA ARCHIWALNE}

Archiwum Główne Akt Dawnych w Warszawie [AGAD]

Archiwum Lubomirskich z Małej Wsi, sygn. 1604.

Archiwum Zamoyskich [AZ], sygn. 3112.

Biblioteka Książąt Czartoryskich w Krakowie rkps 175 .

Centralnyj Derżawnyj Istorycznyj Archiw Ukraini, m. Lviv [CDIAUL]

F. 9, op. 1, ks. 435.

Lvivska Nacional'na Naukova Bibliotieka Ukrajiny imieni Wasylja Stefanyka

F. 5 (Ossolińscy), op. 1, rkps 699.

Nacjanalnyj Histaryczni Archiu Bełarusi, Minsk

F. 695, op. 1, sygn. 48, 55, 99, 100, 142.

\section{STARE DRUKI I EDYCJE ŹRÓDLOWE}

Akta do dziejów króla Jana III sprawy roku 1683, a osobliwie wyprawy wiedeńskiej wyjaśniające, oprac. F. Kluczycki, Kraków 1883.

Akta grodzkie i ziemskie z czasów Rzeczypospolitej Polskiej z archiwum tak zwanego bernardyńskiego we Lwowie, t. XXIV (Lauda sejmikowe halickie 1575-1695), oprac. A. Prochaska, Lwów 1931.

Dupont F., Pamiętniki historyi życia i czynów Jana III Sobieskiego, tłum. B. Spieralska, oprac. D. Milewski, Warszawa 2011.

Jemiołowski M., Pamiętnik dzieje Polski zawierający (1648-1679), oprac. J. Dzięgielewski, Warszawa 2000.

Mikołaj Złotnicki i jego diariusz wojenny, oprac. M. Wagner, „Biuletyn Biblioteki Jagiellońskiej” 1994, t. XLV, nr 1/2, s. 101-133.

${ }^{31}$ Więcej o marszu i koncentracji armii koronnej w 1683 r. vide: J. Wi mmer, Wiedeń $1683 \ldots$,. passim. 
Pasek J.Ch., Pamiętniki, oprac. W. Czapliński, Warszawa 2009.

Pułaski F., Krótka annotacja sejmów warszawskich, grodzieńskich, także elekcyi i koronacyi najjaśniejszych królów ichmościów polskich Jana Kazimierza, Michała, Jana III i Augusta II; tudzież za panowania ich kampanii corocznie odprawionych; publiczniejszych dziejów i rewolucyi ab anno 1648, ad annum 1733, Lublin 1740.

Volumina legum, t. V, oprac. J. Ohryzko, Petersburg 1860.

\section{OPRACOWANia}

Hundert Z., Dyslokacja partii wojska koronnego w 1677 roku. Przyczynek do badań pogranicza polsko-tureckiego oraz organizacji armii w dobie pokoju 1677-1683, „Klio: Czasopismo poświęcone dziejom Polski i powszechnym" 2016, nr 1 (36), s. 41-67.

Hundert Z., Pozycja Jana III w wojsku koronnym w latach 1674-1683. Utrzymanie czy też utrata wpływów wypracowanych w czasie sprawowania godności hetmańskiej?, [w:] Król Jan III Sobieski i Rzeczpospolita w latach 1674-1683, red. D. Milewski, Warszawa 2016, s. 121-151.

Koczegarow K., Rzeczpospolita a Rosja w latach 1680-1686. Zawarcie traktatu o pokoju wieczystym, thum. z jęz. rosyjskiego z uzupełnieniami, red. T. Szwaciński, Warszawa 2017.

Nagielski M., Żolnierz koronny w XVII wieku. Wybawca i bohater czy ciemiężyciel - w świetle zachowanych rejestrów szkód w księgach grodzkich i ziemskich Rzeczypospolitej, [w:] Społeczeństwo Staropolskie, t. IV (Społeczeństwo a wojsko), red. I. Dacka-Gorzyńska, M. Nagielski, A. Karpiński, Warszawa 2015, s. 135-154.

Wagner M., Armia koronna w latach 1677-1678, [w:] Król Jan III Sobieski i Rzeczpospolita w latach 1674-1683, red. D. Milewski, Warszawa 2016, s. 177-200.

Wagner M., Wojna polsko-turecka w latach 1672-1676, t. I-II, Zabrze 2009.

Wimmer J., Wiedeń 1683. Dzieje kampanii oraz bitwy, Warszawa 1983.

Wimmer J., Wojsko polskie w drugiej połowie XVII wieku, Warszawa 1965.

\section{ZBIGNIEW HUNDERT}

\section{From Żurawno to Vienna. About requirement for further studies of military quarters of Crown army in period 1677-1683}

$\operatorname{In}$ period between two wars against Ottoman Empire (1677-1683) Crown (Polish) troops were stationed in set-up quarters on the Polish-Turkish border. Main idea behind it was to defend new borders - after losing Podolia to Turks - but also to protect civilian population from the troops stationed (and subsequently marching into the theater of war) in other parts of the country. It was the first time when such system of regular military barracks was introduced. Moreover, soldiers stationed there were required to produce food for themselves. Such picture, drawn from the diaries written during the period, require though further confirmation or verification, especially based on further research of the archives in Lviv and Minsk.

Keywords: the Crown Army in 1677-1683, the Crown Army partia's deployment in 1677-1683, Polish-Ottoman borderlands. 